Bull. Chem. Soc. Ethiop. 2012, 26(3), 429-435.

Printed in Ethiopia

DOI: http://dx.doi.org/10.4314/bcse.v26i3.12

ISSN 1011-3924

(c) 2012 Chemical Society of Ethiopia

\title{
SYNTHESIS AND ANTIMICROBIAL ACTIVITY OF SOME NEW PYRROLE DERIVATIVES
}

\author{
Akbar Idhayadhulla ${ }^{1}$, Radhakrishnan Surendra $\operatorname{Kumar}^{1}$, Abdul Jamal Abdul Nasser ${ }^{1 *}$ \\ and Aseer Manilal ${ }^{2}$ \\ ${ }^{1}$ P.G. \& Research Department of Chemistry, Jamal Mohamed College, Tiruchirappalli- \\ 620020, Tamil Nadu, India \\ ${ }^{2}$ Department of Biotechnology, Presentation College of Applied Sciences, \\ Puthenvelikara 683594, Tamil Nadu, India
}

(Received October 26, 2011; revised July 16, 2012)

\begin{abstract}
New pyrrole derivatives were synthesized and structures were confirmed by IR, ${ }^{1} \mathrm{H}$ NMR, ${ }^{13} \mathrm{C}$ NMR, mass spectra, and elemental analyses data. The reaction was performed by using ordinary condensation type, which enabled to easy work-up and good yield. Synthesized compounds were screened for antimicrobial
\end{abstract} activity.

KEY WORDS: Pyrrole, 1,3,4-oxadiazol-2-amine, 4H-1,2,4-triazol-3-ol, Cyclization, Antimicrobial activity, Structure activity relationship

\section{INTRODUCTION}

Pyrrole derivatives are of considerable synthetic importance due to their extensive used in drug discovery [1] which is linked to their pharmacological activity such as anti-inflammatory [2], cytotoxicity [3-6], treatment of hyperlipidemias [7] and antitumour agents [8]. The pyrrole containing other heterocyclic compounds has been reported previously for biological studies [9]. Oxadiazole linked with pyrrole derivatives are display a broad spectrum of biological activity such as antimicrobial activity [10], antitubercular agents [11]. Triazole linked with pyrrole derivatives have importance of biological and pharmaceutical importance activity such as anti-inflammation [12,13], antitumor [14] and antimicrobial [15-17]. These references will serve as the main rationales for the synthesis of new pyrrole connecting oxadiazole and triazole derivatives (Scheme 1) and evaluate them for antimicrobial activity.

\section{RESULTS AND DISCUSSION}

\section{Chemistry}

Synthesized compounds are outlined in Scheme 1. Diethyl 3,5-dimethyl-1H-pyrrole-2,4-dicarboxylate (1) was prepared by using Fischer and Noller condensation method [18]. The compound 2,2'-[(3,5-dimethyl-1H-pyrrole-2,-diyl)dicarbonyl]dihydrazinecarbox amide (2) was prepared by condensation method [19].

The compound 5,5'-(3,5-dimethyl-1H-pyrrole-2,4-diyl)bis(2,4-dihydro-3H-1,2,4-triazol-3ol) (3) was synthesized from $10 \% \mathrm{NaOH}$ solution and acidification with dilute $\mathrm{HCl}$ by cyclization method $[20,21]$. IR spectrum of the compound 3 showed an absorption band at 1669,3345 and $3301 \mathrm{~cm}^{-1}$ corresponding to $\mathrm{C}=\mathrm{N}, \mathrm{NH}$ and $\mathrm{OH}$, respectively. The ${ }^{1} \mathrm{H}$ NMR spectrum of the compound 3 shows that singlet at $\delta 11.63$ corresponding to $\mathrm{NH}$ in pyrrole ring

*Corresponding author. E-mail: jamal_abdulchem@ymail.com 
and $\mathrm{OH}$ protons resonated as a singlet at $\delta 11.82$, respectively. The ${ }^{13} \mathrm{C}$ NMR spectrum of the compound 3 shows peak at $\delta 161.11$ corresponding to $\mathrm{C}-\mathrm{OH}$ and 155.86 corresponding to $\mathrm{C} 4-\mathrm{C}$ and $\mathrm{C} 2-\mathrm{C}$, respectively. The EI-MS spectrum of the compound $\mathbf{3}$ showed that molecular ion peak at $\mathrm{m} / \mathrm{z} 261.91\left(\mathrm{M}^{+}, 5 \%\right)$, which is conformed to molecular weight of the compound 3 . Scheme 2 shows the mass spectral fragmentation of compound 2.
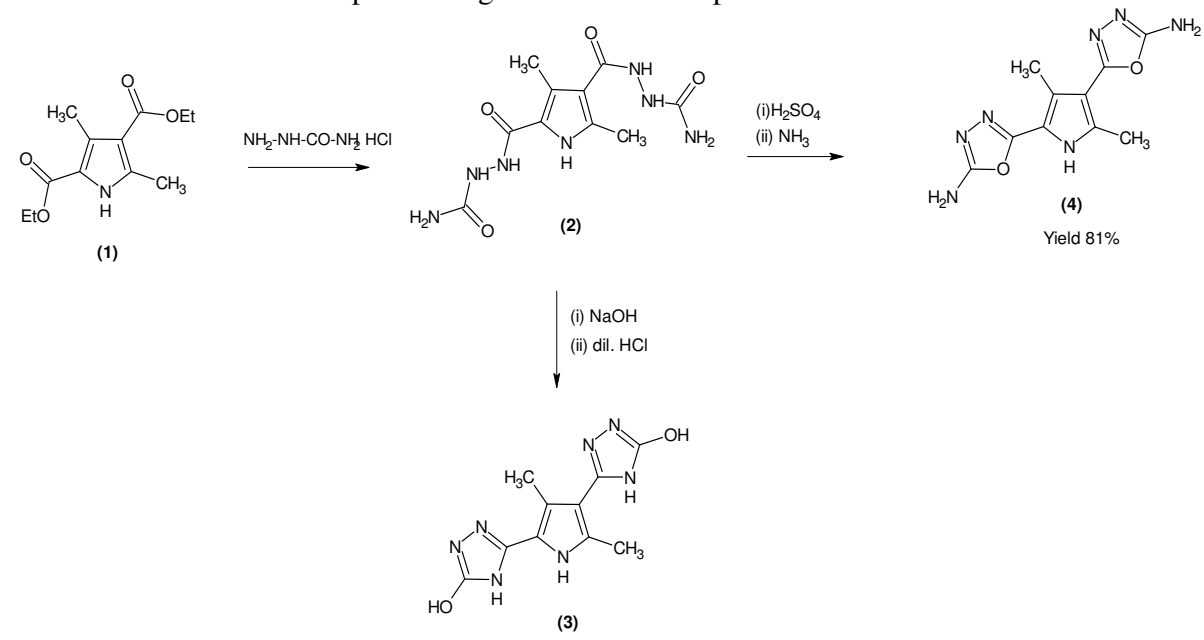

Yield $78 \%$

Scheme 1. Synthesis route of compounds 1-4.

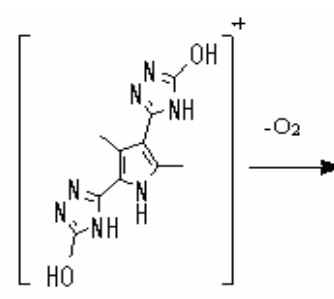

$\mathrm{m} / \mathrm{z} 261.91$

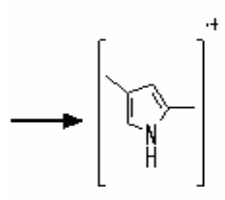

$m 295.76$

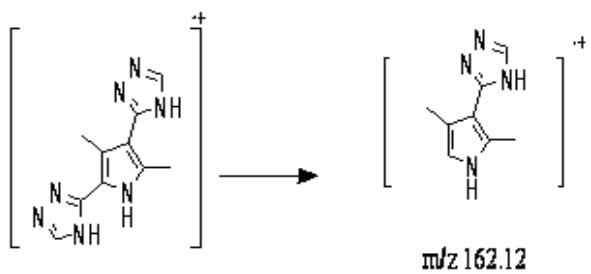

$\mathrm{m} / \mathrm{z} 230.27$

Scheme 2. Mass spectral fragmentation of compound (3).

The compound 5,5'-(3,5-dimethyl-1H-pyrrole-2,4-diyl)bis(1,3,4-oxadiazol-2-amine)(4) was synthesized from compound 2 reacted with $\mathrm{H}_{2} \mathrm{SO}_{4}$ and neutralized with $\mathrm{NH}_{3}$ solution by cyclization method [22]. The IR spectra of compound 4 shows that absorption peak at 669 , $1644,3021,3388$ and $\mathrm{cm}^{-1}$ attributing to $\mathrm{C}-\mathrm{O}-\mathrm{C}, \mathrm{C}=\mathrm{N}, \mathrm{NH}_{2}$ and $\mathrm{NH}$ group, respectively. The ${ }^{1} \mathrm{H}$ 
NMR spectrum of compound 4 shows that signal at $\delta 11.34$ corresponding to $\mathrm{N}-\mathrm{H}$ in pyrrole ring and singlet at $\delta 7.12$ for $\mathrm{NH}_{2}$ protons present in oxadiazole ring and $\mathrm{C} 3-\mathrm{CH}_{3}, \mathrm{C} 5-\mathrm{CH}_{3}$ protons corresponding to singlet at $\delta 2.69$ and 2.93, receptively. The ${ }^{13} \mathrm{C}$ NMR spectrum the compound 4 shows peak at $\delta 168.11,110.73$ and 114.71 corresponding $\mathrm{C}-\mathrm{NH}_{2}, \mathrm{C} 4-\mathrm{C}$ and $\mathrm{C} 2-\mathrm{C}$ respectively. The EI-MS spectrum of the compound 4 showed molecular ion peak at $\mathrm{m} / \mathrm{z} 261.56$ $\left(\mathrm{M}^{+}, 10 \%\right)$, which is conformed to molecular weight of the compound 4 . Scheme 3 shows the mass spectral fragmentation of compound 2 .

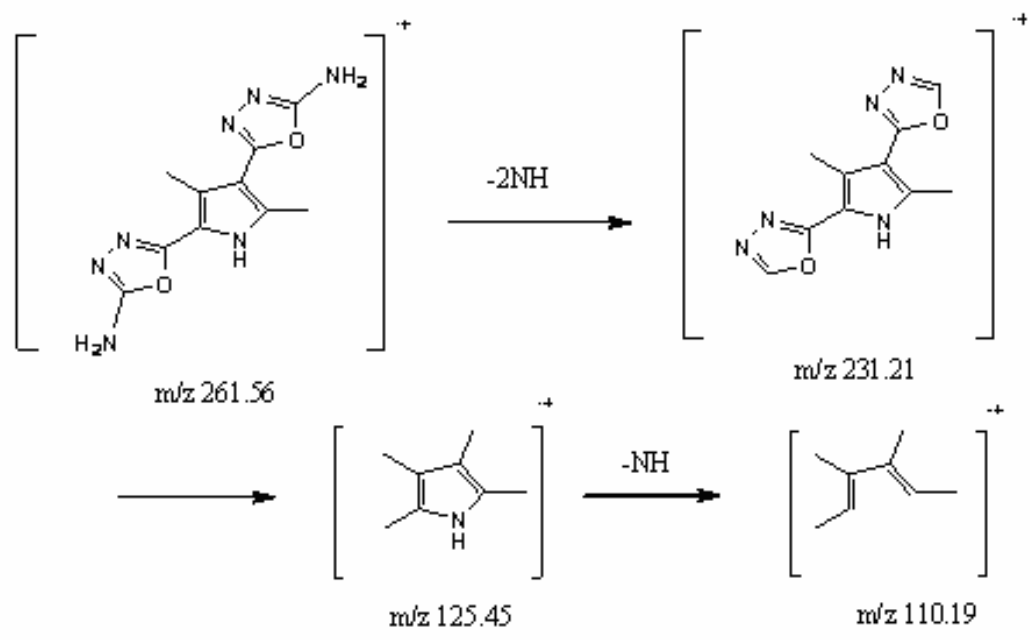

Scheme 3. Mass spectral fragmentation of compound (4).

\section{Antibacterial activity}

The compounds 1-4 were screened for antibacterial activity. Compound $\mathbf{3}$ is highly active than standard (Ciprofloxacin) against $P$. mirabilis and compound $\mathbf{4}$ is highly active than standard against $M$. luteus at concentration $100 \mu \mathrm{g} / \mathrm{mL}$. Figure 1 shows that antibacterial activity of the compound 1-4. The bacterial zones of inhibition $(\mathrm{mm})$ values are summarized in Table 1.

Table 1. Antibacterial activity of compounds (1-4).

\begin{tabular}{|l|l|l|l|l|l|}
\hline \multirow{2}{*}{ Test organisms } & \multicolumn{5}{|c|}{ Compounds } \\
\cline { 2 - 6 } & $\mathbf{1}$ & $\mathbf{2}$ & $\mathbf{3}$ & $\mathbf{4}$ & Standard \\
\hline E. coli $($ MTCC-739) & 10 & 15 & 8 & 15 & 18 \\
\hline P. mirabilis & - & - & 21 & 10 & 15 \\
\hline Non hemolytic streptococcus & 8 & - & 15 & 14 & 16 \\
\hline P. aeruginosa $($ MTCC-2435) & 14 & 15 & - & 20 & 27 \\
\hline M. luteus $($ MTCC-106) & 7 & - & 10 & 23 & 20 \\
\hline E. faecalis & - & - & - & 8 & 29 \\
\hline S. epidermidis & - & 24 & 10 & - & 27 \\
\hline K. pneumoniae & - & 5 & - & - & 21 \\
\hline Bacillus spp & 18 & - & - & 10 & 23 \\
\hline S. aureus $($ MTCC-2940) & - & 16 & 12 & 6 & 16 \\
\hline
\end{tabular}

Zone of inhibition was measured at $(\mathrm{mm})$ at concentration of $100 \mu \mathrm{g} / \mathrm{mL}$, ciprofloxacin is used as the standard. 


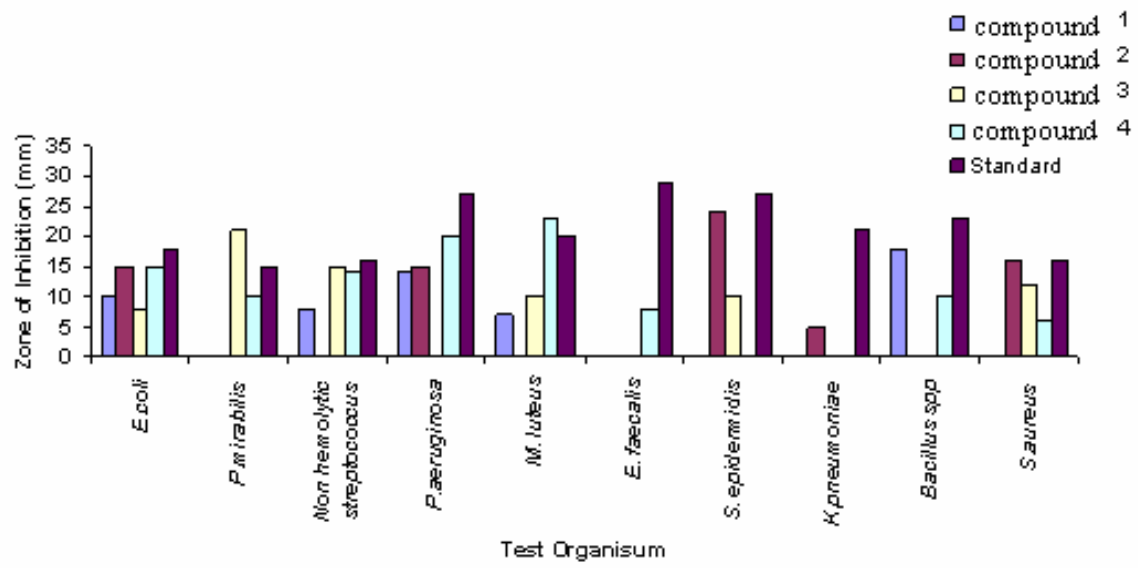

Figure 1. Antibacterial activity of the compound (1-4) and standard.

\section{Antifungal activity}

The compounds 1-4 were screened for the antifungal activity. Compound $\mathbf{3}$ is highly active compared with standard (Clotrimazole) against $A$. niger, the compound $\mathbf{4}$ is highly compared with standard against C. albicans at concentration $100 \mu \mathrm{g} / \mathrm{mL}$. Figure 2 shows that antifungal activity of the compound 1-4. The fungal zones of inhibition $(\mathrm{mm})$ values are summarized in Table 2 .

Table 2. Antifungal activity of compounds (1-4).

\begin{tabular}{|l|c|l|l|l|l|}
\hline \multirow{2}{*}{ Test organisms } & \multicolumn{5}{|c|}{ Compounds } \\
\cline { 2 - 6 } & $\mathbf{1}$ & $\mathbf{2}$ & $\mathbf{3}$ & $\mathbf{4}$ & Standard \\
\hline A. niger & 12 & 16 & 26 & 10 & 22 \\
\hline C. albicans & 8 & 12 & 8 & 20 & 18 \\
\hline C. neoformans & - & 8 & 10 & 5 & 15 \\
\hline M. audouinii & 5 & 16 & 8 & 10 & 16 \\
\hline
\end{tabular}

Zone of inhibition was measured at $(\mathrm{mm})$ at concentration of $100 \mu \mathrm{g} / \mathrm{mL}$, clotrizaole is used as the standard.

\section{Structure activity relationship}

Scheme 4 shows that significance of antibacterial activity in compounds $\mathbf{3}$ and antifungal activity in compounds 4 . From the results of antimicrobial activity of the pyrrole derivatives, the following structure activity relationships can be derived Antibacterial activity of compound $\mathbf{3}$ shows that highly active against $P$. mirabilis and antifungal activity of compound $\mathbf{3}$ shows highly active against $A$. niger at concentration $100 \mu \mathrm{g} / \mathrm{mL}$ due to presence of triazole moiety connected with pyrrole derivative.

Antibacterial activity of compound $\mathbf{4}$ shows that highly active against M. luteus and antifungal activity of compound $\mathbf{4}$ shows highly active against $C$. albicans at concentration 100 $\mu \mathrm{g} / \mathrm{mL}$ due to presence of oxadiazole moiety connected with pyrrole derivative. 


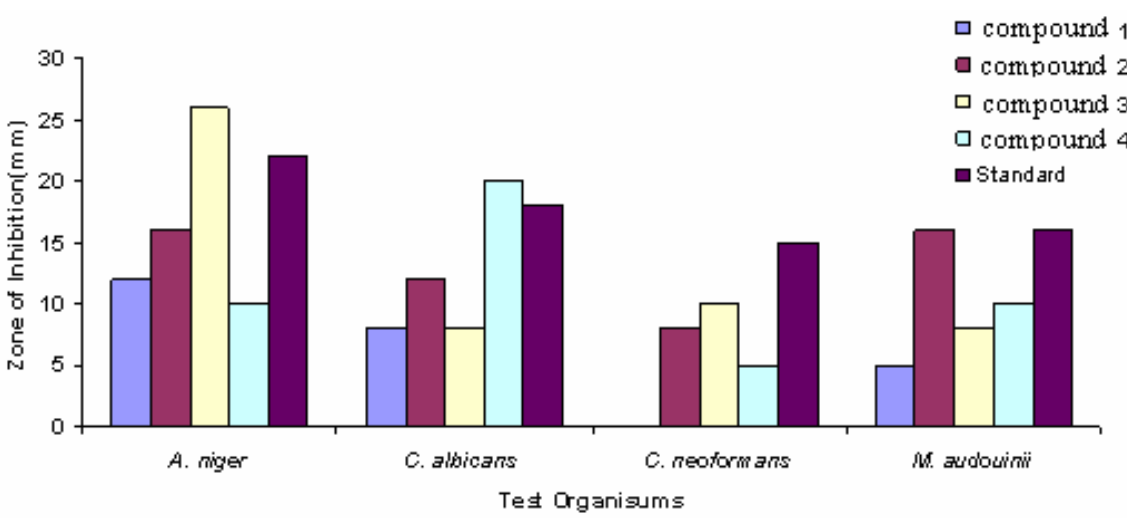

Figure 2. Antifungal activity of the compound (1-4) and standard.
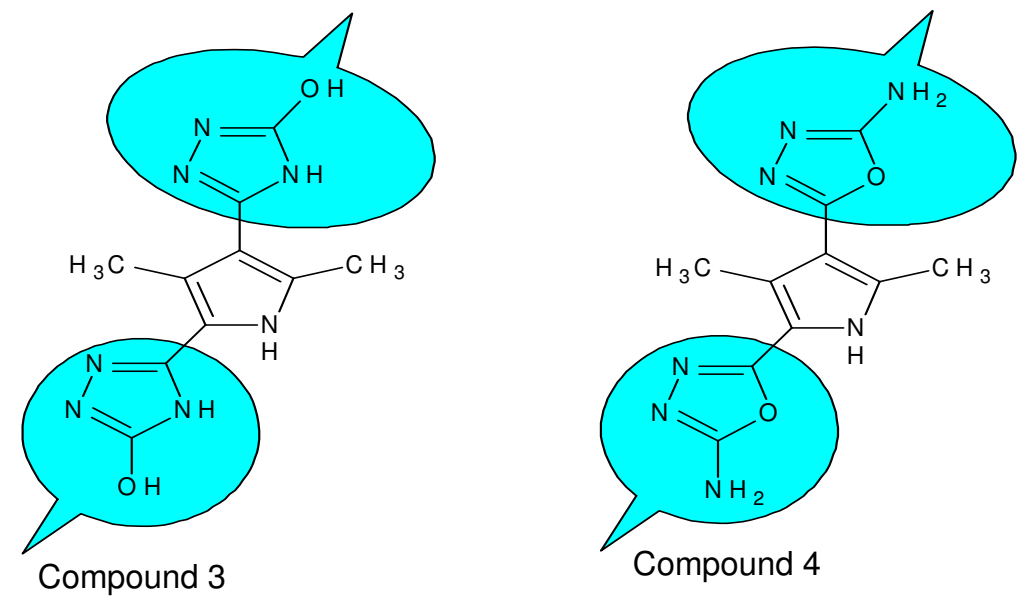

Scheme 4

\section{EXPERIMENTAL}

Melting points were recorded in open capillary tubes and were uncorrected. The IR spectra $(\mathrm{KBr})$ were recorded in $\mathrm{KBr}$ on a shimadzu $8201 \mathrm{pc}\left(4000-400 \mathrm{~cm}^{-1}\right)$. The ${ }^{1} \mathrm{H} \mathrm{NMR}$ and ${ }^{13} \mathrm{C}$ NMR spectra were recorded on a Bruker DRX-300 MHZ. The elemental analysis $(\mathrm{C}, \mathrm{H}$, and N,) were recorded using an Elementer analyzer model (Varian EL III). The purity of the compounds was checked by thin layer chromatography (TLC) with silica gel plates.

\section{2,2'-[(3,5-Dimethyl-1H-pyrrole-2,4-diyl)dicarbonyl]dihydrazinecarboxamide (2)}

A mixture of 2,4-dimethyl-3,5-dicarbethoxypyrrole (1) (2.39 g, $1.0 \mathrm{~mol})$, semicarbazide hydrochloride $(1.22 \mathrm{~g}, 1.0 \mathrm{~mol})$ was added to sodium acetate $(0.20 \mathrm{~g})$ in ethanol $(8.0 \mathrm{~mL})$, the 
reaction mixture was heated and refluxed for $4 \mathrm{~h}$. The reaction mixture was cooled and poured into ice-cooled water. The precipitate was filtered and recrystallized from absolute ethanol.

5,5'-(3,5-Dimethyl-1H-pyrrole-2,4-diyl)bis(4H-1,2,4-triazol-3-ol) (3)

The mixture of compound 2 (2.97 g, $0.1 \mathrm{~mol})$ in $2 \mathrm{~N}-\mathrm{NaOH}$ solution $(20 \mathrm{~mL})$, the reaction mixture was heated and refluxed for $5 \mathrm{~h}$. After cooling, the solution was made acidic with conc. $\mathrm{HCl}$ and the precipitate was collected from filtration and recrystallized from absolute ethanol.

Yield 78\%; m.p. $147{ }^{\circ} \mathrm{C}$; MW 261; $\mathrm{MF} \mathrm{C}_{10} \mathrm{H}_{11} \mathrm{~N}_{7} \mathrm{O}_{2}$; IR $\left(\mathrm{cm}^{-1}\right)$ : $1669.66(\mathrm{C}=\mathrm{N}), 2936.64$ $\left(\mathrm{CH}_{3}\right), 2986.24\left(\mathrm{NH}-i n\right.$ triazole ring), $3301.53(\mathrm{OH}), 3345.22\left(\mathrm{NH}\right.$-in pyrrole ring); ${ }^{1} \mathrm{H}$ NMR $\left(\mathrm{DMSO}_{6}\right) \delta: 11.63(\mathrm{~s}, 1 \mathrm{H}, \mathrm{NH}$ in pyrrole ring $), 7.75(\mathrm{~s}, 1 \mathrm{H}, \mathrm{NH}$ in triazole ring), $2.43(\mathrm{~s}, 3 \mathrm{H}$, $\left.\mathrm{C} 3-\mathrm{CH}_{3}\right), 2.14\left(\mathrm{~s}, 3 \mathrm{H}, \mathrm{C} 5-\mathrm{CH}_{3}\right), 11.82(\mathrm{~s}, 2 \mathrm{H}, \mathrm{OH}) ;{ }^{13} \mathrm{C}$ NMR (DMSO-d 6 ) $\delta: 161.11(\mathrm{C}-\mathrm{OH})$, $155.86(\mathrm{C} 2, \mathrm{C} 4-\mathrm{C}), 135.36\left(\mathrm{C} 5-\mathrm{CH}_{3}\right), 133.36\left(\mathrm{C} 3-\mathrm{CH}_{3}\right), 116.86(\mathrm{C} 2-\mathrm{C}), 108.96(\mathrm{C} 4-\mathrm{C}), 16.98$ $\left(\mathrm{C} 5-\mathrm{CH}_{3}\right), 10.74\left(\mathrm{C} 3-\mathrm{CH}_{3}\right)$; (EI-MS) m/z: $261.91\left(\mathrm{M}^{+}, 4 \%\right), 230.27$ (100\%), 162.12, 95.76. Elemental analysis calculated (found): C 49.09 (49.04), H 4.38 (4.40), N 17.89 (17.94).

5,5'-(3,5-Dimethyl-1H-pyrrole-2,4-diyl)bis(1,3,4-oxadiazol-2-amine) (4)

A mixture of compound 2 (2.97 g, $0.1 \mathrm{~mol})$ was dissolved in $4 \mathrm{~mL}$ con. $\mathrm{H}_{2} \mathrm{SO}_{4}$, the reaction mixture was stirred at room temp for few minutes and left overnight. It was poured on crushed ice. The resulting solid was kept in $\mathrm{NH}_{3}$ for $2 \mathrm{~h}$. The solid was formed and filtered. The solid was recrystallised form ethanol.

Yield 81\%; m.p. $178{ }^{\circ} \mathrm{C}$; MW 261.24; M.F $\mathrm{C}_{10} \mathrm{H}_{11} \mathrm{~N}_{7} \mathrm{O}_{2}$; IR (cm $\left.{ }^{-1}\right): 669.84$ (C-O-C); $1644.92(\mathrm{C}=\mathrm{N}), 3021.96\left(\mathrm{NH}_{2}\right), 3338.85(\mathrm{NH}) ;{ }^{1} \mathrm{H}$ NMR $\left(\mathrm{DMSO}_{-} \mathrm{d}_{6}\right) \delta: 11.34(\mathrm{~s}, 1 \mathrm{H}, \mathrm{NH}), 7.12$ (s, 4H, C-NH $\left.\mathrm{N}_{2}\right), 2.69\left(\mathrm{~s}, 3 \mathrm{H}, \mathrm{C} 3-\mathrm{CH}_{3}\right), 2.93\left(\mathrm{~s}, 3 \mathrm{H}, \mathrm{C} 5-\mathrm{CH}_{3}\right) ;{ }^{13} \mathrm{C} \mathrm{NMR}\left(\mathrm{DMSOd}_{6}\right) \delta: 168.11(\mathrm{C}-$ $\mathrm{NH}_{2}$ ), 130.86 (C2,C4-C), 164.90 (C3-C), 118.70 (C5-C), 114.17 (C2-C), 110.73 (C4-C), 14.90 $\left(\mathrm{C} 5-\mathrm{CH}_{3}\right), 10.33\left(\mathrm{C} 3-\mathrm{CH}_{3}\right)$; (EI-MS) m/z: $261.56\left(\mathrm{M}^{+}, 10 \%\right), 231.21,125.45(100 \%), 110.19$. Elemental analysis calculated (found): C 45.98 (45.97), H 4.24 (4.26), N 37.53 (37.51).

Antimicrobial activity

In vitro antibacterial screening. The compounds 1-4 were evaluated for their in vitro antibacterial activity against Escherichia coli (MTCC-739), Proteus mirabilis, Non-hemelytic streptococcus, Pseudomonas aeruginosa (MTCC-2435), Micrococcus luteus (MTCC-106), Enterococcus feacalis, Streptococcus epidermidis, Bacillus spp, Klebsiella pneumoniae (recultured), and Staphylococcus aureus (MTCC- 96), by disc diffusion method [23] performed using Mueller-Hinton agar (Hi-Media) medium. Ciprofloxacin was used as a standard. Each compound was tested at concentration $100 \mu \mathrm{g} / \mathrm{mL}$ in DMSO. The zone of inhibition (mm) was measured after $24 \mathrm{~h}$ incubation at $37^{\circ} \mathrm{C}$.

In vitro antifungal screening. The compounds 1-4 were evaluated for their in vitro antifungal activity such as Aspergillus niger, Candia albicans, Microsporum audouinii and Cryptococcus neoformans (recultured) using disc diffusion method [24] with sabouraud's dextrose agar (Hi-Media). Clotrimazole was used as a standard. Each compound was tested at a concentration of $100 \mu \mathrm{g} / \mathrm{mL}$ in DMSO. The zone of inhibition $(\mathrm{mm})$ was measured incubated at $37^{\circ} \mathrm{C}$.

\section{ACKNOWLEDGEMENTS}

We wish to thank Department of Microbiology, Bharathidasan University, India for help in the antimicrobial studies. We sincerely thank the management of Jamal Mohamed College for providing the laboratory facilities. 


\section{REFERENCES}

1. Toja, E.; Depaoli, A.; Tuan, G.; Kettenring, J. Synthesis 1987, 272.

2. Joseph, M.; Muchowski Stefan, H.; Unger, T.; Ackrell, J.; Cheung, P.; Gary, F.; Cook, C.J. J. Med. Chem. 1985, 28, 1037.

3. Dannhardt, G.; Kiefer, W.; Kramer,G.; Maehrlein, S.; Nowe,U.; Fiebich,B. Eur. J. Med. Chem. 2000, 35, 499.

4. Khanna, I.K.; Weier, R.M.; Yu, Y.; Collins, P.W.; Miyashiro, J.M.; Koboldt, C.M.; Veenhuizen, A.W.; Currie, A.W.; Seibert,K.; Isakson,P.C. J. Med. Chem. 1997, 40, 1619.

5. Burnham, B.S.; Gupton, J.T.; Krumpe, K.E.; Webb, T.; Shuford, J.; Bowers, B.; Warren, A.E.; Barnes, C.; Hall, I.H. Arch. Pharm. Pharm. Med. Chem. 1998, 331, 337.

6. Gupton, J.T.; Burnham, B.S.; Byrd, B.D.; Krumpe, K.E.; Stokes,C.; Shuford, J.; Winkle, S.; Webb, T.; Warren, A.E.; Barnes, C.; Henry, J.; Hall, I. Pharmazie 1999, 54, 691.

7. Justin, M.H.; O'Toole-Colin, K.; Getzel,A.; Argenti, A.; Michael, A. Molecules 2004, 9, 135.

8. Krowicki, K.; Balzarini, J.; De Clercq, E.; Newman, R.A.; Lown, J.W. J. Med. Chem. 1988, 31,341 .

9. Almerico, A.M.; Diana, P.; Barraja, P.; Dattolo, G.; Mingoia, F.; Loi, A. G.; Scintu, F.; Milia, C.; Puddu, I.; La Colla, P. IL Farmaco 1998, 53, 33.

10. Girges, M.M. Arzneim. Forsch./Drug Res. 1994, 44, 490.

11. Joshi, S.D.; Vagdevi, H.W.; Vaidya, V.P.; Gadaginamath, G.S. Eur. J. Med. Chem. 2008, 43, 1989.

12. Palaska, E.; Sahin, G.; Kelicen, P.; Durlu, N. T.; Altinok, G. Farmaco 2002, 57, 101.

13. Labanauskas, L.; Kalcas, V.; Udrenaite, E. Pharmazie 2001, 56, 617.

14. Demirbaş, N.; Ugurluoglu, R.; Demirbaş, A. Bioorg. Med. Chem. 2002, 10, 3717.

15. Varvaresou, A.; Siatra Papastasikoudi, T.; Tsontinis, A. Farmaco 1998, 53, 320.

16. Aggarwal, N.; Kumar, R.; Dureja, P.; Khurana, J.M. Eur. J. Med .Chem. 2011, 46, 4089.

17. Bayrak, H.; Demirbas, A.; Demirbas, N.; Karaoglu, S.A. Eur. J. Med .Chem. 2010, 45, 4726.

18. Fischer, H.; Noller, C.R. Organic Syntheses Coll. 1943, 2, 202.

19. Srivastava, S.K; Srivastava, S.; Srivastava, S.D. Indian J. Chem. 2002, 41B, 2357.

20. Demir S.; Dincer. M.; Cetin.A. Acta Cryst. 2006. E62, o2198.

21. Hussain,A.; Sharba, K.; Rida, H. Molecules 2005, 10, 115.

22. Ojha, S.; Ameta, U.; Dhakar, N. Indian J. Chem. 2007, 46B, 860.

23. Bauer, A.W.; Kirby, W.M.; Sherris, J.C. Am. Clin. Pathol. 1966, 39, 493.

24. Varma, R.S, Antifungal Agents: Past, Present and Future Prospects, National Academy of Chemistry and Biology: Lucknow, India; 1998. 